\author{
$\mathrm{N}_{2} \mathrm{O}$ 분해를 위한 전이금속이 도핑된 메조포러스 실리카 촉매의 \\ 합성과 표면 특성에 관한 연구 \\ 이갑두 · 노민수 · 박상원 \\ 계명대학교 녹색융합기술연구소 \\ (2012년 1월 6일 접수; 2012년 5월 21일 수정; 2012년 6월 21일 채택)
}

\title{
Synthesis and Surface Characterization of Transition Metal Doped Mesoporous Silica Catalysts for Decomposition of $\mathrm{N}_{2} \mathrm{O}$
}

\author{
Kamp-Du Lee, Min-Soo Noh, Sang-Won Park ${ }^{*}$ \\ Center for Green \& Fusion Technologies, Keimyung University, Daegu 704-701, Korea \\ (Manuscript received 6 January, 2012; revised 21 May, 2012; accepted 21 June, 2012)
}

\begin{abstract}
The purpose of this study is to synthesize transition metal doped mesoporous silica catalyst and to characterize its surface in an attempt to decomposition of $\mathrm{N}_{2} \mathrm{O}$. Transition metal used to surface modification were $\mathrm{Ru}, \mathrm{Pd}, \mathrm{Cu}$ and Fe concentration was adjusted to $0.05 \mathrm{M}$. The prepared mesoporous silica catalysts were characterized by X-ray diffraction, BET surface area, BJH pore size, Scanning Electron Microscopy and X-ray fluorescence. The results of XRD for mesoporous silica catalysts showed typical the hexagonal pore system. BET results showed the mesoporous silica catalysts to have a surface area of 537 $\sim 973 \mathrm{~m}^{2} / \mathrm{g}$ and pore size of $2 \sim 4 \mathrm{~nm}$. The well-dispersed particle of mesoporous silica catalysts were observed by SEM, the presence and quantity of transition metal loading to mesoporous surface were detected by XRF. The $\mathrm{N}_{2} \mathrm{O}$ decomposition efficiency on mesoporous silica catalysts were as follow: $\mathrm{Ru}>\mathrm{Pd}>\mathrm{Cu}>\mathrm{Fe}$. The results suggest that transition metal doped mesoporous silica is effective catalyst for decomposition of $\mathrm{N}_{2} \mathrm{O}$.
\end{abstract}

Key Words : Decomposition, Mesoporous silica, MCM-41, $\mathrm{N}_{2} \mathrm{O}$, Transition metal

\section{1. 서 론}

온실효과(greenhouse effect)를 일으키는 가스들을 온실가스(greenhouse gas)라고 하는데, 대표적으로 이산화탄소 $\left(\mathrm{CO}_{2}\right)$, 휘발성유기화합물(VOCs), 메탄 $\left(\mathrm{CH}_{4}\right)$, 아산화질소 $\left(\mathrm{N}_{2} \mathrm{O}\right)$, 프레온가스 $(\mathrm{CFCs})$, 육불화 황 $\left(\mathrm{SF}_{6}\right)$ 및 대류권의 오존 $\left(\mathrm{O}_{3}\right)$ 등을 들 수 있다. 온실

${ }^{*}$ Corresponding author : Sang-Won Park, Center for Green \& Fusion Technologies, Keimyung University, Daegu 704-701, Korea

Phone: +82-53-580-5212

E-mail: swpark@kmu.ac.kr
효과에 가장 큰 비중을 차지하는 온실가스는 연구자 들의 견해에 따라 다르기는 하지만 이산화탄소 보다 메탄, 프레온가스 및 아산화질소 등이 분자당 온실효 과가 횔씬 크다고 보고되고 있다(Gerard, 1994). 특히, $\mathrm{N}_{2} \mathrm{O}$ 는 성층권의 오존층 파괴와 관련되어 있는 물질 이며, 1997년 COP3(제3회 UN 기후변화조약 체결국 회의)에서 $\mathrm{CO}_{2}, \mathrm{CH}_{4}, \mathrm{CFCs}$ 등과 함께 지구 온난화를 야기하는 중요한 온실가스로 분류되었다. 이산화탄소 에 비해 310 배의 온실효과를 가지며, 농도가 2 배 증가 하면 오존은 $10 \%$ 감소하는 물질로 알려져 있으며, 최 근 지구 대기 중의 $\mathrm{N}_{2} \mathrm{O}$ 의 농도는 매년 약 $0.2 \sim 0.3 \%$ 
씩 증가하고 있다. 연간 4.7 7백 만 톤 정도 대기 중 으로 방출되는데. 발생원으로는 Adipic Acid와 질산 의 제조과정, 자동차의 배기가스와 석탄의 연소, 유동 층의 연소장치, 폐기물의 소각, 유기화학비료를 이용 한 대규모 경작 등의 인위발생원과 자연발생원으로부 터 발생한다(Dann 등, 1995; Perez-Ramirez 등, 1999; Reimer 등, 1994).

$\mathrm{N}_{2} \mathrm{O}$ 는 $400 \sim 1,000^{\circ} \mathrm{C}$ 의 고온에서 촉매 또는 열분 해를 이용하여 분해할 수 있다. 현재까지 $\mathrm{N}_{2} \mathrm{O}$ 감소 및 분해 기술로는 열분해, 기상 열분해, 매체입자에 의한 접촉분해, 분해촉매, 선택적 환원촉매, 비선택적 환원 촉매, 전기화학적 직접분해 등이 있다. 하지만 이 방법 들 중 몇몇 방법은 고온 운전의 경제적인 부담과 비효 율성의 문제점을 가지고 있으며, $\mathrm{NO}_{\mathrm{x}}$ 가 공존할 경우 $\mathrm{N}_{2} \mathrm{O}$ 의 분해 효율이 급격하게 떨어지고 시설설치에 있어서 고비용 부담 등의 문제점이 있다. 실제 $\mathrm{N}_{2} \mathrm{O}$ 를 배출하는 산업체에 기술을 적용시키려면 저온에서 처 리하는 기술을 개발하는 것이 필요하며, 또한 현재 $\mathrm{N}_{2} \mathrm{O}$ 저감을 위해 사용하고 있는 촉매는 거의 수입에 의존하고 있으므로 촉매 제조에 있어서 국내 기술의 개발이 필요하다(Chang, 2008).

과거에는 $\mathrm{N}_{2} \mathrm{O}$ 분해실험에 제올라이트계 촉매들이 많이 연구되어졌다. $\mathrm{SeO}$ 등(2007)은 모더나이트형 제 올라이트에 $\mathrm{Fe}$ 와 $\mathrm{Pd}$ 를 이온 교환하여 담지한 촉매를 이용하여 $\mathrm{N}_{2} \mathrm{O}$ 분해실험을 수행한 결과 $\mathrm{Fe}$ 만 이온 교 환하여 제조한 촉매보다 $\mathrm{Pd}$ 를 담지하여 제조한 $\mathrm{Pd}-\mathrm{Fe}-\mathrm{MOR}$ 촉매가 $25^{\circ} \mathrm{C}$ 낮은 온도에서 동일한 활성 을 나타냈다. 이는 $\mathrm{Pd}$ 가 담지됨으로서 제올라이트에 는 없던 강산점이 생겨 $\mathrm{N}_{2} \mathrm{O}$ 의 선택적 촉매환원반응시 저온부의 활성을 증대시키는 것이라고 하였다. Drago 등(1997)은 silica, magnesium oxide, hydrotalcite 등 의 지지체를 사용한 다양한 금속 촉매들로 $\mathrm{N}_{2} \mathrm{O}$ 분해 메커니즘을 연구하였으나 대부분의 촉매들은 $400^{\circ} \mathrm{C}$ 이상의 온도에서만 $\mathrm{N}_{2} \mathrm{O}$ 분해가 이루어졌다. 또한, Christoforou 등(2002)은 다양한 메탈(Rh, Ru, Pd, Co, $\mathrm{Cu}, \mathrm{Fe}, \mathrm{In})$ 과 담체 $\left(\mathrm{Al}_{2} \mathrm{O}_{3}, \mathrm{SiO}_{2}, \mathrm{TiO}_{2}, \mathrm{ZrO}_{2}\right)$ 를 사용 한 촉매를 제조하여 $\mathrm{N}_{2} \mathrm{O}$ 분해실험을 수행한 결과 $\mathrm{Rh}$ 가 담지된 촉체들의 활성이 우수하다고 하였다. 이밖 에도 Perez-Ramirez 등(2004)이 Fe-제올라이트 촉매 를 사용하여 $\mathrm{CO}$ 환원제 존재 하에서 $\mathrm{N}_{2} \mathrm{O}$ 를 환원시키
는 방법으로 $\mathrm{N}_{2} \mathrm{O}$ 분해 실험을 한 결과 단일성분의 분 해성능보다 향상되었음을 확인하였으나 역시 $400^{\circ} \mathrm{C}$ 이상의 고온에서 활성을 나타내는 문제점을 보였다.

따라서 본 연구에서는 전이금속 $(\mathrm{Ru}, \mathrm{Pd}, \mathrm{Cu}, \mathrm{Fe})$ 이 도핑된 메조포러스 실리카(mesoporous silica) 촉매를 제조 및 표면 특성을 분석하고, $\mathrm{N}_{2} \mathrm{O}$ 분해 실험을 통해 저온에서의 촉매 활성을 확인하며, 이를 바탕으로 연 료 절감을 통한 경제적 효과뿐만 아니라 촉매 제조에 있어서 국내 기술을 확보하는 기반을 마련하는데 목 적을 두고 있다.

\section{2. 재료 및 방법}

\section{1. 실험 재료 및 방법}

본 연구에서는 메조포러스 실리카 촉매를 계면활 성제와 실리카의 몰 비를 조절하여 제조하였다. 양이 온 계면활성제인 CTMABr(cetyltrimethyl ammonium bromide, Sigma 99\%)인 $\mathrm{C}_{19} \mathrm{H}_{42} \mathrm{NBr}$ 을 구조유도체로 사용하였으며, 실리카 재료(silica source)는 TEOS (tetraethyl orthosilicate, Aldrich 98\%)를 사용하였다.

계면활성제 $1.84 \mathrm{~g}$ 을 증류수 $90 \mathrm{~mL}$ 와 에탄올 $(\mathrm{EtOH}) 153.6 \mathrm{~mL}$ 를 혼합하여 실온에서 $1 \mathrm{~h}$ 교반한다. $\mathrm{NaOH} 0.46 \mathrm{~g}$ 을 첨가한 후 10 분 교반하고, 이 용액에 TEOS $10.25 \mathrm{~mL}$ 를 교반하면서 천천히 첨가하였다. 이때 합성 혼합물 내의 반응물의 몰 조성은 $0.9 \mathrm{TEOS}$ : $0.1 \mathrm{CTMABr}: 0.1 \mathrm{NaOH}: 100 \mathrm{H} 2 \mathrm{O}: 50 \mathrm{EtOH}$ 이다.

위 혼합물을 실온에서 $1 \mathrm{~h}$ 교반시킨 후 autoclave 속 에 넣고 $90^{\circ} \mathrm{C}$ 에서 $24 \mathrm{~h}$ 수열합성 하였다. 반응 용기를 $70^{\circ} \mathrm{C}$ 로 냉각시킨 후 재빨리 여액을 제거하고 침전물 을 여과한 후 생성물에 들어있는 계면활성제를 제거 하기 위하여 에탄올과 염산 $(\mathrm{HCl})$ 의 혼합물 $(0.1 \mathrm{M}$ $\mathrm{HCl}$-에탄올 용액)로 세척한 후 한 번 더 여과한 다음, $70^{\circ} \mathrm{C}$ 에서 $24 \mathrm{~h}$ 건조시켜 $550^{\circ} \mathrm{C}$ 로 $3 \mathrm{~h}$ 소성처리 하여 분 말을 얻는다. 순수한 메조포러스 실리카는 $\mathrm{N}_{2} \mathrm{O}$ 를 분 해시킬 수 있는 활성점을 가지고 있지 않기 때문에 전 이금속을 메조포러스 실리카의 표면에 도핑하여 표면 개질을 시킴으로 활성점을 가지도록 한다.

메조포러스 실리카 촉매의 표면개질과정은 다음과 같다. 메조포러스 실리카 $1 \mathrm{~g}$ 과 $0.05 \mathrm{M}$ 전이금속 용액 $(\mathrm{Ru}, \mathrm{Pd}, \mathrm{Cu}, \mathrm{Fe}) 10 \mathrm{ml}$ 를 혼합하여 $0.1 \mathrm{M} \mathrm{HCl}$ 용액으 
로 $\mathrm{pH}$ 를 조절한 후 $24 \mathrm{~h}$ 교반하고, 다시 $0.1 \mathrm{M} \mathrm{NaOH}$ 용액을 이용하여 $\mathrm{pH}$ 를 조절한 뒤 $12 \mathrm{~h}$ 교반하고, 증류 수로 세척한 다음, 여과를 하고 나온 분말을 $70^{\circ} \mathrm{C}$ 에서 $24 \mathrm{~h}$ 건조 후 질소분위기에서 $600^{\circ} \mathrm{C}$ 로 $3 \mathrm{~h}$ 소성처리 하 였다. 이렇게 제조된 메조포러스 실리카 촉매들을 $\mathrm{Ru}-\mathrm{MS}, \mathrm{Pd}-\mathrm{MS}, \mathrm{Cu}-\mathrm{MS}, \mathrm{Fe}-\mathrm{MS}$ 라 명명하였다.

메조포러스 실리카 촉매의 결정구조 및 구조의 강도를 알아보기 위하여 X-선 회절분석기(X-ray diffractometer, XRD, D/Max-2500, Rigaku)를 이용하 고, $\mathrm{N}_{2}$ 흡탈착 장치(BET, ASAP2020, Micromeritics Instrument Corp. U.S.A)를 이용하여 비표면적은 BET (Brunauer-Emmett-Teller) 식을 적용하고, 기공 크기 분포는 BJH(Barrett-Joyner-Halenda) 식을 적용 하여 구하였으며, 메조포러스 실리카 촉매의 입자상 태, 입자구조 및 균일성을 관찰하기 위하여 주사전자 현미경(Scanning Electron Microscopy, SEM, S-4300 \& EDX-350, Hitachi)를 사용하였다. 또한, 전이금속 의 유무확인과 함유율을 확인하기 위하여 X선 형광분 석법(X-Ray Fluorescence, XRF, Phlips PW2400, U.S.A)을 사용하였다.

\section{2. $\mathrm{N}_{2} \mathrm{O}$ 분해 실험 방법 및 장치}

본 연구에서 메조포러스 실리카 촉매의 활성을 평 가하기 위하여 $\mathrm{N}_{2} \mathrm{O}$ 제거 실험을 실시하였다. $\mathrm{N}_{2} \mathrm{O}$ 제 거 실험에 사용된 가스는 $\mathrm{N}_{2} \mathrm{O}(3,000 \mathrm{ppm}$ in $\mathrm{He})$ 를 사 용하였으며, 촉매의 온도 변화에 따라 분해되는 가스 의 농도를 측정하여 촉매의 성능을 평가하였다. 촉매 의 온도는 $300^{\circ} \mathrm{C} \sim 500^{\circ} \mathrm{C}$ 로 조절하였으며, 실험에 사 용한 반응기는 고온에서 견딜 수 있도록 직경 $2 \mathrm{~cm}$ 의 석영반응기를 이용하였다. 석영반응기에 표면개질화 된 메조포러스 실리카 촉매를 규정량 채우고 온도 컨 트롤러(HANYOUNG, NP200)를 이용하여 $300^{\circ} \mathrm{C}$ 까 지 온도를 올려준 다음, $\mathrm{He}(99.99 \%$ 이상)을 흘려보내 $3 \mathrm{~h}$ 유지시켜 전처리를 하고, $100^{\circ} \mathrm{C}$ 까지 온도가 떨어진 후 다시 온도를 올려가며 MFC(Mass flow controller) 를 이용하여 분해할 $\mathrm{N}_{2} \mathrm{O}$ 가스를 정확히 주입시켜 촉 매의 $\mathrm{N}_{2} \mathrm{O}$ 분해 반응 특성을 알아보았다.

온도는 $100^{\circ} \mathrm{C}$ 에서 시작하여 $100^{\circ} \mathrm{C} / \mathrm{h}$ 씩 올라가도록 하며 $200^{\circ} \mathrm{C}, 300^{\circ} \mathrm{C}, 400^{\circ} \mathrm{C}$ 그리고 $500^{\circ} \mathrm{C}$ 에서 각 30 분 동안 온도를 고정시켜 분해 실험을 실시하였다. 반응
후 생성되는 gas의 조성 변화는 Gas Chromatograph (GC, HP6890A)를 검출기는 TCD(Thermal Conductivity Detector)를 사용하였고, 컬럼은 길이 $30 \mathrm{~m}$ 에 직경이 $0.530 \mathrm{~mm}$ 인 HP- MOLESIEVE 컬럼을 사용하여 분 석하였다.

실험 조건은 Table 1 에 나타내었으며, 장치에 대한 모식도는 Fig. 1에 나타내었다.

Table 1. Experimental Conditions

\begin{tabular}{cc}
\hline Item & Condition \\
\hline \hline Temperature & $200 \sim 500^{\circ} \mathrm{C}$ \\
\hline Analyzing gas concentration $\left(\mathrm{N}_{2} \mathrm{O}\right)$ & $3,000 \mathrm{ppm}$ \\
\hline Carrier gas & $\mathrm{He}(99.99 \%$ 이상 $)$ \\
\hline Injector temperature & $185^{\circ} \mathrm{C}$ \\
\hline Detector temperature & $150^{\circ} \mathrm{C}$ \\
\hline Oven temperature & $35^{\circ} \mathrm{C}$ \\
\hline Gas flow & $30 \mathrm{cc} / \mathrm{min}$ \\
\hline
\end{tabular}

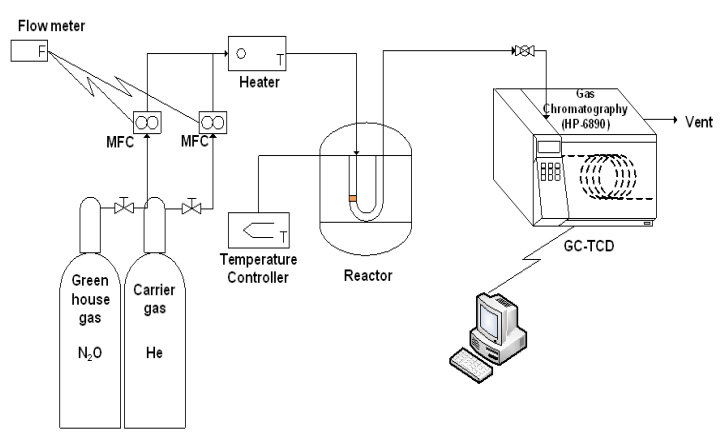

Fig. 1. Schematic diagram of $\mathrm{N}_{2} \mathrm{O}$ conversion.

\section{3. 결과 및 고찰}

\section{1. 메조포러스 실리카 촉매의 특성분석}

메조포러스 실리카 촉매의 표면특성을 분석하기 위하여 XRD, BET, SEM, XRF 분석을 실시하였다. Fig. 2는 메조포러스 실리카 촉매의 결정구조 및 구조 의 강도를 알아보기 위하여 $\mathrm{XRD}$ 를 분석한 결과이다. 분석결과를 보면 $2 \Theta=2 \sim 6^{0}$ 에서 (100), (110), (200)의 회절피크를 뚜렷하게 관찰할 수 있는데, 이는 본 연구 에서 제조된 메조포러스 실리카 촉매가 전형적인 MCM-41의 hexagonal 구조를 띠고 있음을 알 수 있 
으며,(Pandurangan 등, 2005; Zhang 등, 2005) 구조적 균일성이 뛰어나다는 것을 알 수 있다. 그리고 전이금 속이 도핑된 메조포러스 실리카 촉매의 피크를 보면 강도가 감소하는 것을 볼 수 있는데, 이는 전이금속이 메조포러스 실리카 촉매의 표면에 성공적으로 도핑 되었다는 것을 의미한다(Chen 등, 2010).

Table 2는 메조포러스 실리카 촉매의 비표면적, 기 공크기, 기공부피를 보여준다. 순수 메조포러스 실리 카 촉매의 비표면적은 $973 \mathrm{~m}^{2} / \mathrm{g}$, 전이금속이 도핑된 메조포러스 실리카 촉매의 비표면적은 $537 \sim 658$ $\mathrm{m}^{2} / \mathrm{g}$ 으로 비표면적이 감소된 것을 볼 수 있다. 비표면 적에 비해 기공크기와 기공부피는 큰 변화가 없었다. 즉 전이금속의 도핑은 비표면적에 영향을 주며, 비표 면적의 감소는 전이금속이 $\mathrm{MCM}$ 의 표면에 도핑되었 음을 의미한다( $\mathrm{Lu}$ 등, 2009).

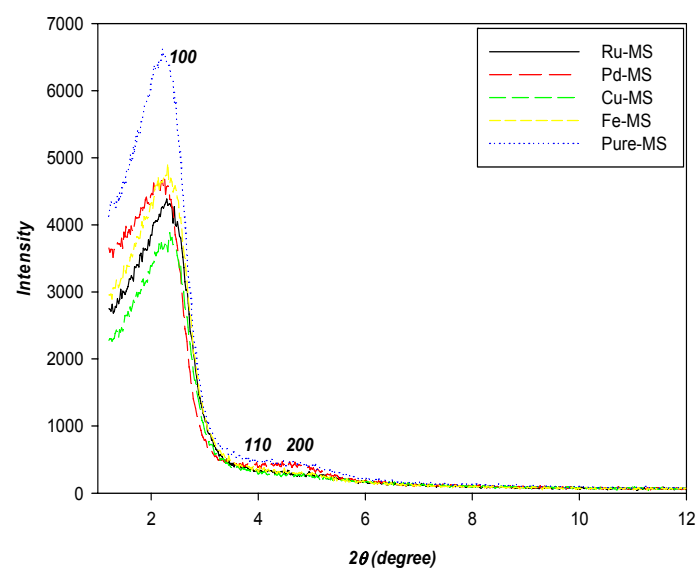

Fig. 2. X-ray diffraction patterns of transition metal doped mesoporous silica catalysts.

Table 2. Surface Area, pore diameter, and pore volume of the prepared transition metal doped mesoporous silica catalysts

\begin{tabular}{ccc}
\hline & $\begin{array}{c}\text { BET Surface Area } \\
\left(\mathrm{m}^{2} / \mathrm{g}\right)\end{array}$ & $\begin{array}{c}\text { Total } \\
\text { pore volume } \\
\mathrm{V}_{\mathrm{p}}\left(\mathrm{cm}^{3} / \mathrm{g}\right)\end{array}$ \\
\hline \hline Ru-MS & 551 & 1.84 \\
\hline Pd-MS & 658 & 2.03 \\
\hline Cu-MS & 537 & 1.78 \\
\hline Fe-MS & 601 & 2.07 \\
\hline Pure-MS & 973 & 2.34 \\
\hline
\end{tabular}

Fig. 3은 메조포러스 실리카 촉매의 $\mathrm{N}_{2}$ 흡착-탈착 등온곡선을 나타낸 것으로, 이 곡선은 IUPAC에서 정 의한 Type IV 형태의 흡착 등온 곡선을 가지고 있다. Type IV 형태는 15 1000 ̊의 세공 반경을 갖는 즉, 중간 세공을 가지고 있는 다공성물질에서 나타난다 (IUPAC, 1972). 또한, 모든 등온선들은 히스테리시스 (Hysteresis)현상을 보이고 있는데, 이는 메조포러스 실리카의 세공 구조 때문에 나타나는 현상으로 기체 압력을 높여가면서 측정한 흡착 등온선과 기체의 압 력을 낮추어가며 얻은 흡착 등온선이 서로 일치되지 않는 현상으로 세공에 흡착되어 응축된 액체의 메니 스커스 때문에 나타난다. 이는 흡착될 때와 탈착될 때 메니스커스의 반지름과 모양이 서로 다르기 때문이다 (Shirlkar 등, 2002; Wei 등, 2010).

흡착-탈착 등온선에서 $\mathrm{y}$ 축은 단위질량당 흡착된 질 소의 부피를 나타내는데 전이금속을 도핑함으로서 흡 착량이 감소하는 것으로 볼 때, 메조기공의 부피가 감 소함을 알 수 있다. 분석결과에서 나타나듯이 낮은 상 대압력 $\mathrm{P} / \mathrm{P}_{0}$ 에서 질소는 메조포러스 실리카의 기공의 표면에 단분자층(monolayer)으로 흡착되며, 0.3 0.4 부근에서는 질소의 흡착량이 급격히 증가하는 것을 볼 수 있는데, 이는 질소의 다중흡착층(multilayer)이 메조기공을 메움으로써 발생하는 현상으로 메조 pore 분자체의 특징적인 현상이다(Teller 등, 1977).

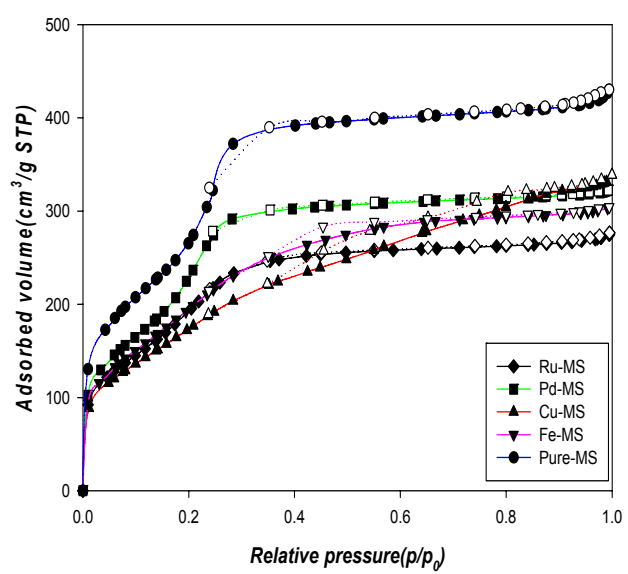

Fig. 3. $\mathrm{N}_{2}$ adsorption/desorption isotherm of $(\nabla)$ Ru-MS, $(\boldsymbol{\square})$ Pd-MS, ( $\boldsymbol{\Delta})$ Cu-MS, ( $\boldsymbol{\nabla})$ Fe-MS and Pure-MS. 
Fig. 4는 메조포러스 실리카 촉매의 $\mathrm{N}_{2}$ 흡착-탈착 등온 곡선으로부터 $\mathrm{BJH}$ 방법에 의해 구한 기공크기 분포 곡선을 나타낸 것이다. 분석결과에서 나타나듯 이 메조포러스 실리카 촉매 모두 2 4 nm 사이의 균일 한 기공분포를 가지는 것을 알 수 있다.

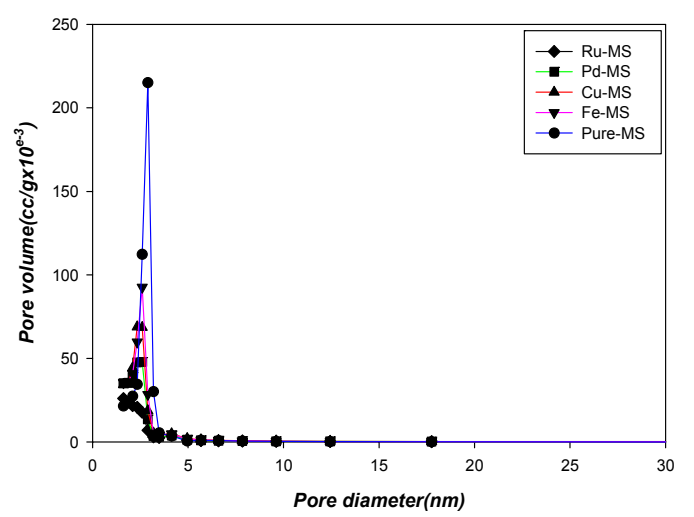

Fig. 4. Pore size distribution of $(\nabla)$ Ru-MS, $(\square)$ Pd-MS, $(\mathbf{\Delta}) \mathrm{Cu}-\mathrm{MS},(\boldsymbol{\nabla}) \mathrm{Fe}-\mathrm{MS}$ and $(\mathbf{O})$ Pure-MS.
Fig. 5는 표면개질화 된 메조포러스 실리카 촉매의 입자표면을 주사전자현미경(SEM)을 통해 분석한 결 과이다. 분석결과에서 나타나듯이 순수한 메조포러스 실리카 촉매와 전이금속이 도핑된 메조포러스 실리카 촉매 모두 비교적 균일한 구형 입자구조를 가지고 있 음을 확인할 수 있으며, 이는 실리카의 기공 속으로 전 이금속의 도핑이 잘 이루어졌음을 나타낸다.

위와 같은 결과로부터 본 연구에서 제조된 메조포 러스 실리카 촉매는 지지체(support)로서의 가치가 높 을 뿐만 아니라 $\mathrm{N}_{2} \mathrm{O}$ 가스를 처리하는데 있어 적합한 물질로 사용할 수 있음을 보여준다.

Fig. 6 7은 메조포러스 실리카 촉매의 표면에 전 이금속의 도핑 유무를 확인하기 위하여 $\mathrm{X}$ 선 형광분석 (XRF)을 실시한 결과이다. 분석결과에서 나타나듯이 전이금속을 도핑 시킨 메조포러스 실리카 촉매마다 각 원소만의 고유한 $\mathrm{K}_{\mathrm{a}}$ 값과 $\mathrm{K}_{\beta}$ 값을 관찰할 수 있는 데, 이로부터 메조포러스 실리카 촉매 표면에 전이금 속이 도핑 되어 있음을 확인할 수 있으며, $\mathrm{N}_{2} \mathrm{O}$ 분해

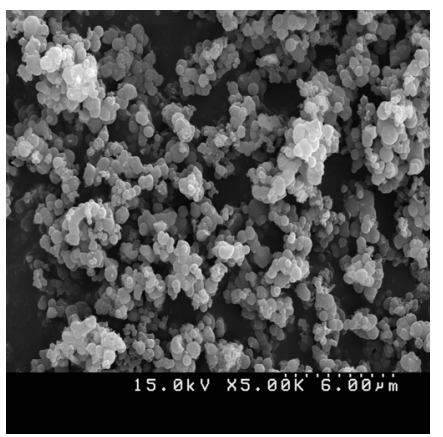

(a) Ru-MS

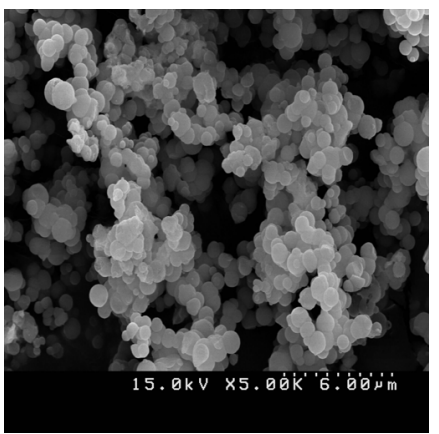

(b) Pd-MS

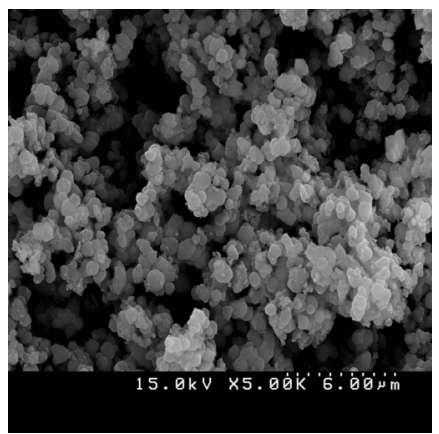

(c) $\mathrm{Cu}-\mathrm{MS}$

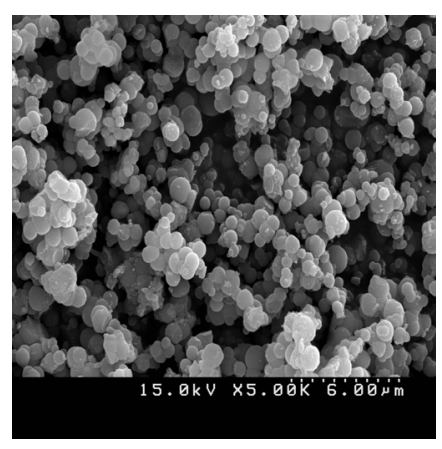

(d) Fe-MS

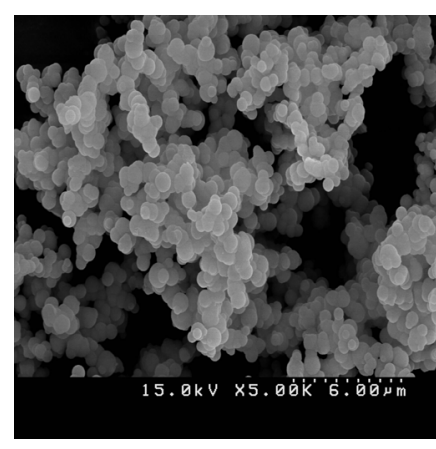

(e) Pure-MS

Fig. 5. SEM image of (a) Ru-MS, (b) Pd-MS (c) Cu-MS, (d) Fe-MS, (e) Pure-MS. 


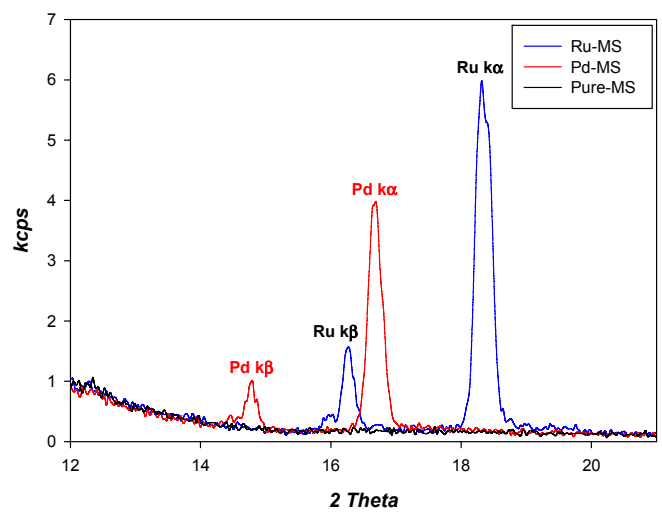

Fig. 6. XRF patterns of Ru-MS, Pd-MS and Pure-MS

기능을 충분히 발휘할 수 있을 것으로 판단된다.

Table 3은 메조포러스 실리카 촉매의 전이금속 함 유율을 나타낸 것으로 $\mathrm{Ru} 7.603 \%, \mathrm{Cu} 10.311 \%, \mathrm{Fe}$ $4.61 \%, \operatorname{Pd} 3.849 \%$ 의 함유율을 나타내었다. 반면, 전 이금속의 농도가 같은 $0.05 \mathrm{M}$ 의 용액으로 표면개질 화를 시켰음에도 불구하고, 함유율이 다른 것은 전이 금속 각각의 전기적 특성 및 분자 값 등에 따라 메조포 러스 실리카 촉매 표면에 흡착되는 정도의 차이로 사 료된다.

Table 3. Concentration of $\mathrm{SiO}_{2}$ and transition metal in mesoporous silica catalysts

\begin{tabular}{ccc}
\hline & $\mathrm{SiO}_{2}(\%)$ & Transition Metal(\%) \\
\hline \hline Ru-MS & 91.109 & 7.603 \\
\hline Pd-MS & 96.151 & 3.849 \\
\hline Cu-MS & 89.689 & 10.311 \\
\hline Fe-MS & 95.384 & 4.616 \\
\hline Pure-MS & 100 & 0 \\
\hline
\end{tabular}

\section{2. $\mathrm{N}_{2} \mathrm{O}$ 분해 효율 평가}

$\mathrm{N}_{2} \mathrm{O}$ 분해는 일정 온도 수준이 되면 활성점을 가지 는 촉매와 반응하여 분해가 된다. 일반적으로 촉매를 이용한 $\mathrm{N}_{2} \mathrm{O}$ 분해 메커니즘은 다음과 같이 알려져 있 다(Kantcheva와 Vakkasoglu, 2004; Hadjiivanov 등, 2006; Moulijn 등, 1996; Muhler 등, 2002).

$$
\mathrm{N}_{2} \mathrm{O}+(\mathrm{M}) \rightarrow \mathrm{N}_{2}+\mathrm{O} \cdot(\mathrm{M})
$$

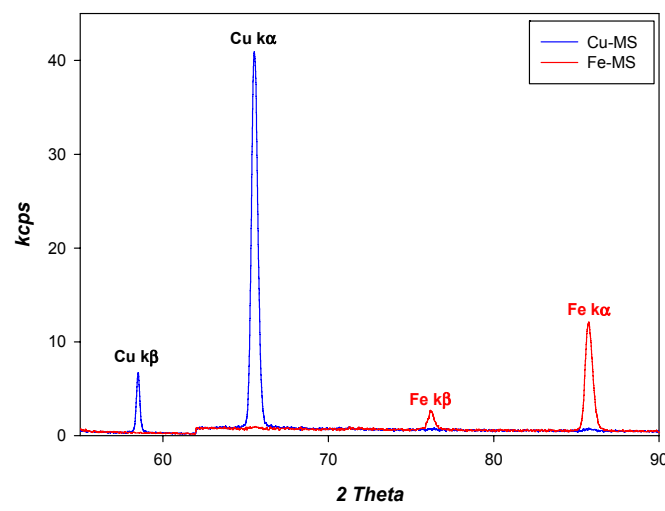

Fig. 7. XRF patterns of $\mathrm{Cu}-\mathrm{MS}$ and Fe-MS.

$$
\begin{aligned}
& 2 \mathrm{O} \cdot \mathrm{M} \leftrightharpoons \mathrm{O}_{2}+2(\mathrm{M}) \\
& \mathrm{N}_{2} \mathrm{O}+\mathrm{O} \cdot(\mathrm{M}) \rightarrow \mathrm{N}_{2}+\mathrm{O}_{2}+(\mathrm{M})
\end{aligned}
$$

(M)은 금속산화물촉매의 활성점을 나타내며, 반응 식 (1)에서 $\mathrm{N}_{2} \mathrm{O}$ 는 촉매로부터 전자를 받으면 질소와 산소 원자 이온으로 분해가 되고, 질소는 흡착되지 않 으나 전자를 받아 생성된 산소 이온은 촉매 표면에 흡 착하게 된다. 이렇게 흡착된 산소이온은 반응식 (2)와 같이 흡착 산소종들의 재결합에 의해 탈착되게 된다. 또는 반응식 (3)과 같이 $\mathrm{N}_{2} \mathrm{O}$ 와 흡착된 산소이온과 반 응하여 $\mathrm{N}_{2}$ 와 $\mathrm{O}_{2}$ 로 제거된다.

기 이론을 바탕으로 본 실험에서는 표면개질된 메 조포러스 실리카 촉매의 온도 변화에 따른 성능 평가 를 위하여 $\mathrm{N}_{2} \mathrm{O}$ 분해 실험을 실시하였다. 분해 실험은 $\mathrm{N}_{2} \mathrm{O}$ 표준가스의 초기 농도는 $3,000 \mathrm{ppm}, 1$ 회 실험 시 사용되는 메조포러스 실리카 촉매의 양은 $0.2 \mathrm{~g}$ 으로 고정시켰다. Fig. 8 은 $\mathrm{N}_{2} \mathrm{O}$ 분해 실험 결과를 나타낸 것이다. 분해 실험 결과를 보면 $500^{\circ} \mathrm{C}$ 에서 $\mathrm{Ru}-\mathrm{MS}$ $99 \%$, Pd-MS $80 \%$, Cu-MS 77\%, Fe-MS 56\%의 분해 효율을 보여준다. 이는 전이금속의 활성도 크기 $(\mathrm{Ru}>\mathrm{Pd}>\mathrm{Cu}>\mathrm{Fe})$ 와 일치하는 결과이다. 국외 연구에 서 살펴보면, Kawi 등(2001)의 $\mathrm{Ru}$ 를 도핑하여 $\mathrm{N}_{2} \mathrm{O}$ 를 제거한 결과 $500{ }^{\circ} \mathrm{C}$ 에서 $100 \%$ 의 제거율을 보이고 있 으며, Pd-Al-Co를 도핑한 Granger 등(2008)의 연구 결과를 보면 $74 \%$ 의 제거율을 나타내고 있다. 또한 Koh 등(2006)과 Prins 등(2007)의 Fe-I와 Fe-ZSM를 
이용한 연구 결과를 보면 약 $50 \%$ 의 제거율로 본 연구 와 비교해 볼 때, 비슷한 $\mathrm{N}_{2} \mathrm{O}$ 분해 효율을 볼 수 있다. 국내의 경우, 이 (2010)가 연구한 산화코발트 $\left(\mathrm{CO}_{3} \mathrm{O}_{4}\right)$ 촉매를 이용하여 $\mathrm{N}_{2} \mathrm{O}$ 를 분해한 결과 $450{ }^{\circ} \mathrm{C}$ 에서 약 $75 \%$ 의 제거율을 나타냈으며, $\mathrm{MMO}(\mathrm{Co}-\mathrm{Pd}-\mathrm{Al})$ 촉매 를 이용한 유 (2009)의 연구 결과를 살펴보면 $500^{\circ} \mathrm{C}$ 에 서 $86 \%$ 의 제거율을 나타냄으로서 본 연구에서 제조 된 촉매의 성능이 뛰어난 것을 알 수 있다.

순수 메조포러스 실리카 촉매의 경우 온도가 증가 하면 $\mathrm{N}_{2} \mathrm{O}$ 분해 효율은 높아지지만 그 차이는 미세하 다. 이는 촉매로서의 활성도가 거의 일어나지 않음을 의미한다. 또한, 메조포러스 실리카 촉매의 표면 특성 분석 결과와 $\mathrm{N}_{2} \mathrm{O}$ 분해 효율과의 상관관계를 살펴보 면, BET 결과의 경우 순수 실리카 촉매의 비표면적이 $973 \mathrm{~m}^{2} / \mathrm{g}$ 으로 전이금속이 도핑된 촉매보다 월등히 높 게 나타났지만 $\mathrm{N}_{2} \mathrm{O}$ 분해율은 $10 \%$ 미만으로 가장 낮 게 나타났다. 이는 $\mathrm{N}_{2} \mathrm{O}$ 의 제거 메커니즘이 비표면적 에 의한 흡착이 아닌 전이금속 촉매의 활성점에 의한 분해라는 것을 알 수 있다. 그리고 전이금속 $(\mathrm{Ru}, \mathrm{Pd}$, $\mathrm{Cu}, \mathrm{Fe}$ )이 도핑된 촉매의 비표면적을 비교해보면 537 $\sim 658 \mathrm{~m}^{2} / \mathrm{g}$ 으로 약간의 차이는 있지만 비슷한 것을 볼 수 있으며, $\mathrm{N}_{2} \mathrm{O}$ 분해율과 연관 지어 살펴보면, 분 해율의 차이는 전술한 전이금속의 활성도 차이와 일 치하는 것을 알 수 있다. 또한 $\mathrm{N}_{2} \mathrm{O}$ 분해 반응 메커니 즘에서는 흡착된 산소이온이 탈착하는 단계가 속도결 정 단계이므로, 탈착되는 산소로부터 전자를 받을 수 있는 정공이 많아야 반응이 빨라짐으로 활성도가 높

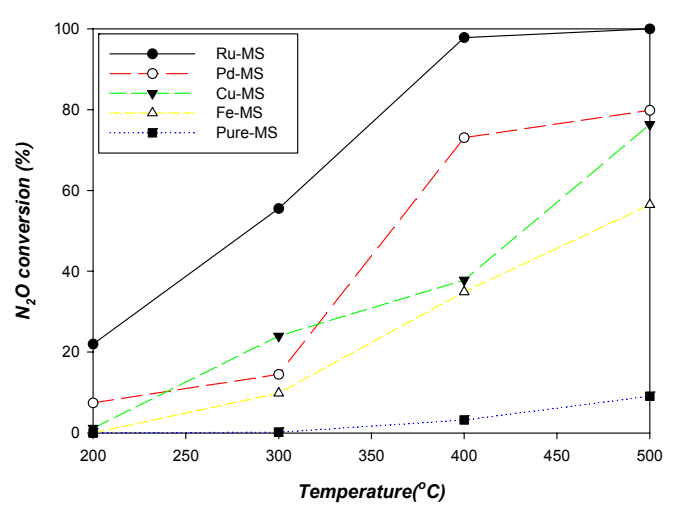

Fig. 8. $\mathrm{N}_{2} \mathrm{O}$ conversion of transition metal doped mesoporous silica catalysts.
은 전이금속을 도핑할수록 정공이 많아져 전기전도도 가 높아지고, 이로 인해 반응도 빨라진다고 사료된다.

따라서 본 연구에서는 $\mathrm{N}_{2} \mathrm{O}$ 분해에 있어서 전이금 속의 도핑이 필요하다는 사실을 보여주며, 또한 전이 금속을 도핑함으로서 $500^{\circ} \mathrm{C}$ 이상의 고온에서 $\mathrm{N}_{2} \mathrm{O}$ 를 분해시킬 수 있던 기존 공정에 비해 표면개질된 본 연 구의 메조포러스 실리카 촉매를 이용할 경우 저온에 서도 상당한 분해 효율을 나타낼 수 있다.

\section{4. 결 론}

본 연구에서는 메조포러스 실리카에 $0.05 \mathrm{M}$ 전이 금속 용액 $(\mathrm{Ru}, \mathrm{Pd}, \mathrm{Cu}, \mathrm{Fe})$ 을 혼합하여 메조포러스 실 리카 촉매를 제조하고, $\mathrm{XRD}, \mathrm{N}_{2}$ 흡착-탈착, $\mathrm{BET}$, $\mathrm{BJH}, \mathrm{SEM}, \mathrm{XRF}$ 분석을 통하여 표면 특성 분석을 하 였으며, $200{ }^{\circ} \mathrm{C} \sim 500^{\circ} \mathrm{C}$ 에서의 $\mathrm{N}_{2} \mathrm{O}$ 분해 실험을 통하 여 메조포러스 실리카 촉매의 성능을 평가한 결과 다 음과 같은 결론을 얻었다.

가. 메조포러스 실리카 촉매의 특성분석 결과를 살 펴보면, XRD 분석결과 (100), (110), (200)의 회절피 크를 관찰할 수 있었으며, 구조적 균일성이 뛰어나다 는 것을 알 수 있었다. $\mathrm{N}_{2}$ 흡탈착 분석을 통해 다공성 물질의 IV형 그래프를 확인했고, BET 분석 결과를 통 해 전이금속의 도핑은 비표면적에 영향을 주는 것을 알 수 있었다. $\mathrm{BJH}$ 분석 결과 메조포러스 실리카 촉매 의 균일한 기공 분포를 확인할 수 있었으며, XRF 분 석을 통해 촉매 표면에 전이금속이 도핑과 함유율도 확인할 수 있었다. SEM 분석 결과 메조포러스 실리카 촉매 모두 비교적 균일한 구형 입자구조를 가지고 있 음을 확인했다.

나. 메조포러스 실리카 촉매의 효율평가 측면에서 살펴보면, $\mathrm{N}_{2} \mathrm{O}$ 분해 실험 결과 $500^{\circ} \mathrm{C}$ 에서 $\mathrm{Ru}-\mathrm{MS}$ $99 \%$, Pd-MS $80 \%$, Cu-MS 77\%, Fe-MS 56\%의 분해 효율을 나타냈다. 이는 전이금속의 활성도 크기 $(\mathrm{Ru}>\mathrm{Pd}>\mathrm{Cu}>\mathrm{Fe})$ 와 일치했으며, 저온에서도 분해효율 을 나타내 경제성 면에서 효과를 볼 수 있을 것으로 판 단된다.

본 연구는 메조포러스 실리카 촉매에 전이금속을 도핑함으로서 $500^{\circ} \mathrm{C}$ 이상의 고온에서 $\mathrm{N}_{2} \mathrm{O}$ 를 분해시 
킬 수 있던 기존 공정에 비해 표면개질 된 본 연구의 메조포러스 실리카 촉매를 이용할 경우 저온에서도 상당한 분해 효율을 나타낼 수 있어 경제적 측면뿐만 아니라 촉매 제조에 있어 국내 기술 확보 측면에서도 효과를 나타낼 것으로 사료된다. 그러나 본 연구에서 는 메조포러스 실리카 촉매의 표면 특성 분석에 중점 을 두었기 때문에 향후 기 효과를 완벽하게 달성하기 위해서는 $\mathrm{N}_{2} \mathrm{O}$ 분해 실험에 대한 추가적인 연구가 수 행되어야 할 것으로 사료된다.

\section{감사의 글}

본 연구는 2009년 한국 환경기술진흥원의 지원으 로 수행한(차세대 환경기술개발사업)연구 성과의 일 부입니다.

\section{참 고 문 헌}

유경창, $2009, \mathrm{~N}_{2} \mathrm{O}$ 촉매 분해의 실용화 기초 연구, 석사 학위논문, 상명대학교.

이은영, 2011, 산화코발트 촉매의 제조 및 반응 조건이 $\mathrm{N}_{2} \mathrm{O}$ 분해에 미치는 영향, 석사학위논문, 광운대학교.

Brunauer, S., Emmett, P. H., Teller, E., 1977, Adsorption of gases in multimolecular layers, Journal of the American Chemical Society, 60, 1938.

Chang, K. S., 2008, Status and Trends of Emission Reduction Technologies and CDM Projects of Greenhouse Gas Nitrous Oxide, J. Korean Ind. Eng. Chem., 19, 17-26.

Chen, C., Sona, W. J., Youb, K. S., Ahnb, J. W., Ahna, W. S., 2010, Carbon dioxide capture using amineimpregnated HMS having textural mesoporosity, Chem. Eng. J., 161, 46-52.

Christoforou, S. C., Efthimiadis, E. A., Vasalos, I. A., 2002, Catalytic conversion of $\mathrm{N}_{2} \mathrm{O}$ to $\mathrm{N}_{2}$ over metal-based catalysts in the presence of hydrocarbons and oxygen, Catalysis Letters, 79, 137-147.

Dann, T. W., Schulz, K. H., Mann, M., Collings, M., 1995, Supported rhodium catalysts for nitrous oxide decomposition in the presence of $\mathrm{NO}, \mathrm{CO}_{2}, \mathrm{SO}_{2}$ and CO, Applied Catalysis B: Environmental, 6, 1-10.

Drago, R. S., Jurczyk, K., Kob, N., 1997, Catalyzed decomposition of $\mathrm{N}_{2} \mathrm{O}$ on metal oxide supports,
Applied Catalysis B: Environmental, 13, 69-79.

Gerard, G. de Soete, 1994, Proceedings of the 6th International Workshop on $\mathrm{N}_{2} \mathrm{O}$ emissions, 5 .

Granger, P., Dacquin, J. P., Dujardin, C., 2008, Catalytic decomposition of $\mathrm{N}_{2} \mathrm{O}$ on supported $\mathrm{Pd}$ catalysis: Support and thermal ageing effects on the catalytic performances, Catalysis Today, 30, 390-396.

Hadjiivanov, K., Venkov, T., Dimitrov, M., 2006, FTIR spectroscopic study of the nature and reactivity of $\mathrm{NO}_{\mathrm{x}}$ compounds formed on $\mathrm{Cu} / \mathrm{Al}_{2} \mathrm{O}_{3}$ after coadsorption of $\mathrm{NO}$ and $\mathrm{O}_{2}$, Journal of Molecular Catalysis A: Chemical, 243, 8-16.

IUPAC, 1972, Manual of Symbols and Terminology, Appendix 2,Part 1, Colloid and Surface Chemistry, Pure Appl. Chem., 31, 578.

Kantcheva, M., Vakkasoglu, A. S., 2004, Cobalt supported on zirconia and sulfated zirconia I. FT-IR spectroscopic characterization of the $\mathrm{NO}_{\mathrm{x}}$ species formed upon $\mathrm{NO}$ adsorption and $\mathrm{NO} / \mathrm{O}_{2}$ coadsorption, Journal of Catalysis, 223, 352-363.

Kawi, S., Liu, S. Y., Shen, S. C., 2001, Catalytic decomposition and reduction of $\mathrm{N}_{2} \mathrm{O}$ on Ru/MCM-41 cataltst, Catalysis Today, 68, 237-244.

Koh, C. A., Boissel, V., Tahir, S., 2006, Catalytic decomposition of $\mathrm{N}_{2} \mathrm{O}$ over monolithic supported noble metal-transition metal oxides, Applied Catalysis B: Environmental, 64 234-242.

Lu, C., Su, F., Hsu, S. C., Chen, W., Bia, H., Hwang, J., F., Lee, H. H., 2009, Thermodynamics and regeneration of $\mathrm{CO}_{2}$ adsorption on mesoporous spherical-silica particles., Feul. Process. Tech., 90(12), 1543-1549.

Moulijn, J. A., Kapteijn, F., Rodriguez-Mirasol, J., 1996, Heterogeneous catalystic decomposition of nitrous oxide, Applied Catalysis B: Environmental, 9, 25-64.

Muhler, M., Busser, G. W., Hinrichsen, O., 2002, The temperature-programmed desorption ofoxygen from an alumina-supported silver catalyst, Catalysis Letters, 79, 1-4.

Pandurangan, A., Udayakumar, S., Sinha, P. K., 2005, Mesoporous material as catalyst for the production of fine chemical: Synthesis of dimethyl phthalate assisted by hydrophobic nature MCM-41, Journal of Molecular Catalysis A: Chemical, 240, 139-154. 
Perez-Ramirez, J., Overeijinder, J., Jacob F. K., Moulijn, A., 1999, Structural Promotion and Stabilizing Effect of $\mathrm{Mg}$ in the Catalytic Decomposition of Nitrous Oxide Over Calcined Hydrotalcite-like Compounds, Applied Catalysis B: Environmental, 23, 59-73.

Perez-Ramirez, J., Kumar, M. S., Brückner, A., 2004, Reduction of $\mathrm{N}_{2} \mathrm{O}$ with $\mathrm{CO}$ over FeMFI zeolites: influence of the preparation method on the iron species and catalytic behavior, Journal of Catalysis, 223, 13-27.

Prins, R., Pirngruber, G. D., Roy, P. K., 2007, The role of autoreduction and oxygen mobility in $\mathrm{N}_{2} \mathrm{O}$ decomposition over Fe-ZSM-5, Journal of Catalysis, 246, 147-157.

Reimer, R. A., Slaten, C. S., Seapan M., Lower M. W., Tomlinson P. E., 1994, Abatement of $\mathrm{N}_{2} \mathrm{O}$ emissions produced in the adipic acid industry, Environmental progress, 13(2), 134-137.
Seo, M. H., Lee, S. K., Cho, S. S., Kang, K. H., Song, J. H., 2007, Characterization and Development of Zeolite Catalyst for Nitrous Oxide Reduction, Journal of Energy \& Climate Change 2007, 2(1), 15-22.

Shirlkar, V. P., Joshi, U. D., Joshi, P. N., Tamhankar, S. S., Joshi, V. P., Idage, B. B., Joshi, V. V., 2002, Influence of the size of extraframework monovalent cations in X-type zeolite on their thermal behavior, Thermochimica Acta, 387, 121-130.

Wei, J., Liao, J., Xiao, Y., Zhang P., Shi, Y., 2010, Capture of carbon dioxide by amine-impregnated as-synthesized MCM-41, J. Envron. Sci., 22(10), 1558-1563.

Zhang, C., Liu, Q., Xu, Z., 2005, Synthesis and characterization of non-crystalline mesoporous silicon oxynitride MCM-41 with high nitrogen content, Journal of Non-Crystalline Solids, 351, 1377-1382. 